\title{
Efektivitas Komunikasi Interpersonal Pelatih Dalam Membentuk Karakter Siswa Sekolah Sepakbola di Kota Palembang
}

\author{
Sunarto \& Ratu Mutialela Caropeboka \\ Magister Ilmu Komunikasi Universitas Bina Darma
}

\begin{abstract}
Interpersonal communication in training soccer students between coaches and students is still not effective in shaping character. Effective interpersonal communication between trainers and school students is needed so that students who have character, character, honesty, hard work, discipline, and nationalism based on Pancasila are needed. This study aims to analyze the effectiveness of interpersonal communication between trainers and students in shaping student character. The trainer's interpersonal communication effectiveness variables include: material, method, and time; while the student character variables are limited to: religious, honest, hard work, disciplined, and nationalist. Data analysis in this study used descriptive statistical analysis and inferential analysis uses Structural Equation Modeling (SEM). Data were analyzed using LISREL 8.7 statistical software. The results of the study based on the statistical analysis of the structural equation model (Structural Equation Modeling) obtained a t-value of $4.56>1.96$ and the Standardized Solution of 0.50 . This means that it is concluded that the effectiveness of coach interpersonal communication has a positive and significant effect in shaping the character of football school students in the city of Palembang. The effectiveness of the coach's interpersonal communication has a direct effect of 50 percent in shaping the character of students. The higher the effectiveness of interpersonal communication between trainers and students, the more it will improve the character building of students, so that later students with religious, honest, hard-working, disciplined and nationalist characters are formed based on Pancasila).
\end{abstract}

Keywords: Effectiveness of coach interpersonal communication, student character, structural equation modeling

\section{Pendahuluan}

Sepakbola merupakan salah satu cabang olahraga yang paling banyak digemari masyarakat Indonesia, mulai dari lapisan anak-anak sampai dengan orang dewasa terutama laki-laki. Secara psikologis, anak laki-laki lebih aktif dan tertarik pada sepakbola, karena sebagian besar anak laki-laki selalu mempertontonkan ketrampilan geraknya dalam berbagai situasi.

Di kota Palembang, untuk pembinaan sepakbola usia muda banyak disalurkan lewat sekolah sepakbola (SSB). Sekolah sepakbola memiliki peranan yang sangat penting dalam mengembangkan sepakbola di masyarakat terutama pada tingkatan akar rumput. Sekolah sepakbola merupakan salah satu cara atau metode yang praktis bagi pelatih untuk mengajak siswa-siswanya secara aktif dari berbagai kalangan untuk menggemari olahraga. Sekolah sepakbola bertujuan untuk menampung dan membina anak-anak muda yang berkeinginan untuk bermain sepakbola dengan diberi pelatihan, baik teori dasar dan ketrampilan bermain bola dengan benar. Tujuan lainnya adalah bahwa dengan kegiatan bermain sepakbola, secara bertahap anak-anak dididik bagaimana bersikap dan berperilaku, yang pada akhirnya terbentuk karakter yang baik.

Komunikasi interpersonal merupakan peristiwa yang seharusnya muncul setiap saat. Komunikasi jenis ini dapat terjadi antara pelatih dengan siswa, atau antara siswa dengan siswa. Namun, karena pelatih yang memegang kendali di SSB, penanggung jawab utama kegiatan komunikasi interpersonal yang komunikatif terletak pada tangan pelatih.

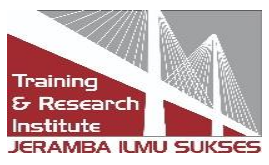


Komunikasi interpersonal melibatkan dua orang dan bersifat pribadi, sebab keduanya memiliki hubungan untuk saling mempercayai juga memahami dan meningkatkan komunikasi dari hati ke hati. Komunikasi dilakukan secara langsung, misalnya melalui percakapan tatap muka, melalui telepon atau dalam bentuk pesan melalui whatsAPP (WA) secara pribadi.

De Vito (2018) menyatakan, bahwa apabila seseorang berkomunikasi dengan orang lain, maka seseorang tersebut telah belajar dengan dirinya sendiri dan juga memperoleh pemahaman penting melalui proses belajar dan interaksi dengan orang lain. Dengan berkomunikasi dan berinteraksi dengan orang lain, diharapkan seseorang mampu belajar untuk menghormati perbedaan pandangan, sikap, perilaku, dan perbedaan budaya dimana seseorang itu dibesarkan. Sebab dengan jalan berinteraksi seseorang akan menemukan karakter yang ada pada dirinya.

Karakter setiap orang berbeda-beda sebab karakter adalah akhlak atau budi pekerti, sifat kejiwaan dimana setiap orang dengan orang lainnya memiliki perbedaan. Seseorang berkarakter maka seseorang itu mempunyai karakter, berperilaku, memiliki kepribadian, memiliki tabiat dan watak. Karakter merupakan pendidikan budi pekerti, pendidikan watak, norma, moral dengan tujuan untuk membantu peserta didik mengembangkan jati diri kearah yang lebih baik dalam kehidupan sehari-hari (Gunawan, 2017).

Hasil observasi penelitian dengan beberapa pelatih di sekolah sepakbola Palembang, diketahui bahwa masih banyak siswa yang cenderung kurang percaya diri (pendiam, pemalu, dan minder), kurang disiplin, kurangnya kesadaran akan tanggung jawab, kurang memperhatikan pelajaran, sering mengganggu kawannya atau sering datang terlambat, sehingga permasalahan ini harus segera diselesaikan oleh pelatih agar nantinya dapat membuat sikap siswa menjadi siswa yang berkarakter (Wawancara dengan pelatih Persegrata, pelatih Putra Sukma, dan pelatih Perisai tanggal 05 Januari 2020).

Menurut Azwar (2016) bahwa pemahaman diri mengenai sikap sangat penting dalam mempelajari masalah perubahan dan pengubahan sikap, tidak saja dalam mencoba mengerti sebab-sebab berubahnya sikap seseorang terhadap sesuatu objek tetapi juga dalam memahami mengapa orang berperilaku tidak sesuai dengan sikapnya. Salah satu cara untuk mengatasi masalah sikap dan perilaku siswa agar menjadi siswa yang berkarakter tersebut pelatih diharapkan mampu meningkatkan pemahaman diri para siswa.

Perubahan sikap dan perilaku siswa sebagai dasar pedoman pelatih untuk menanamkan nilai karakter siswa. Seperti pemahaman perubahan sikap yang dijelaskan dalam teori Johari Window, teori disonansi kognitif Festinger (Azwar, 2016; West dan Turner, 2017), dan teori konsistensi afektif-kognitif Rosenberg (Azwar, 2016). Berdasar uraian, peneliti akan melakukan penelitian berjudul: "Efektivitas komunikasi interpersonal pelatih dalam membentuk karakter siswa sekolah sepakbola di kota Palembang"

\section{Tinjauan Literatur}

\subsection{Komunikasi, Proses Komunikasi Interpersonal}

Definisi komunikasi dilihat dari sudut istilah (terminologis) adalah sebuah proses dimana pesan disampaikan dari seseorang kepada orang lain. Carl I. Hovland, Janis, dan Kelly (1953) dalam Susanto (2018), bahwa komunikasi merupakan proses penyampaian pesan dalam bentuk rangsangan atau kata-kata dari komunikator kepada komunikan dengan tujuan untuk mengubah perilaku. Menurut Berelson dan Steiner (1964) dalam Roudhonah (2019) menyatakan, bahwa komunikasi adalah proses penyampaian informasi, ide, dengan menggunakan lambang-lambang dalam bentuk perkataan, angka atau gambar. 
Laswell (1960) dalam Roudhonah (2019) mengatakan bahwa komunikasi adalah proses yang menjelaskan "siapa", mengatakan "apa", "dengan saluran apa", "kepada siapa" dan "dengan akibat atau hasil apa" (who? says what? In which channel? to whom? With what effect?).

Bila kita pahami dari semua pendapat yang mewakili diatas, maka komunikasi didefinisikan sebagai sebuah proses, dimana pesan disampaikan oleh komunikator kepada komunikan, yang mana pesan-pesan tersebut bisa berupa lambang bahasa maupun isyarat, gaya, atau gambar, dan antara komunikator dan komunikan memiliki kesamaan makna sehingga komunikasi berjalan dengan lancar.

Panuju (2018) mengemukakan, bahwa proses komunikasi ialah langkah/ tahap penciptaan sebuah informasi sehingga terjadi kegiatan komunikasi.

Definisi Komunikasi Interpersonal ialah sebuah proses komunikasi dimana dilakukan secara langsung oleh dua orang individu, bisa berlangsung secara berhadapan (face to face), bisa juga melalui sebuah medium telepon (Roudhonah, 2019).

De Vito (2018) berpendapat, bahwa komunikasi interpersonal bisa dilakukan oleh dua orang atau sekelompok kecil orang. Dalam menyampaikan pesannya, komunikasi jenis ini dilakukan dengan langsung oleh komunikator kepada komunikan..Jadi, menurut De Vito, dalam komunikasi interpersonal terdapat elemen-elemen pokok yaitu antara orang atau sekelompok kecil orang, pesan-pesan, efek dan feedback (umpan balik).

Menurut Barnawi et al. (2014) dalam Caropeboca dan Isnawijayani (2020), bahwa karakter merupakan cara berfikir dan berperilaku yang menjadi ciri setiap individu untuk hidup dan bekerjasama, baik dalam lingkungan keluarga, masyarakat, bangsa dan negara dengan ditunjukkan perilaku yang bertanggung jawab kepada setiap keputusan dan mempertanggungjawabkan setiap akibat dari keputusan yang telah diambilnya. Dapat disimpulkan bahwa semua nama dari karakter merupakan ciri pribadi yang meliputi hal-hal, seperti prilaku, kebiasaan, ketidaksukaan/kesukaan, potensi, nilai-nilai dan pola-pola pemikiran.

\subsection{Teori Jendela Johari (Johari Window)}

Salah satu teori untuk mempelajari kepribadian seseorang adalah dengan menggunakan konsep Jendela Johari (Johari Window). Konsep ini dikembangkan oleh Joseph Luft dan Harry Ingham pada tahun 1955, yang kemudian disingkat dengan nama Johari. Menurut Hutagalung (2007), Kerangka analisa hubungan ini berupa jendela, yang menggambarkan jendela komunikasi seseorang atas kemauan sendiri untuk memberi dan menerima umpan balik, baik berbentuk informasi, pujian maupun kritik dari orang lain untuk kepentingan pengembangan kepribadian seseorang.

Joseph Luft dan Hary Ingham menggambarkan hubungan diri seseorang itu sebagai sebuah jendela. Jendela pertama berisi hal-hal yang diketahui oleh diri sendiri dan oleh orang lain, maka disebut daerah terbuka. Jendela kedua berisi sesuatu yang tidak diketahui diri sendiri tetapi orang lain mengetahui, maka disebut daerah buta. Jendela ketiga berisi hal-hal yang diketahui oleh diri sendiri namun tidak diketahui oleh orang lain (disebut daerah tersembunyi). Sedangkan jendela yang keempat berisi sesuatu yang diri sendiri tidak tahu maupun orang lain juga tidak tahu. Jendela yang keempat ini dinamakan daerah tidak sadar (Hutagalung, 2007; Harapan dan Ahmad, 2014).

Menurut Hutagalung (2007) dalam bukunya berjudul Pengembangan Kepribadian, menyatakan bahwa bagian I dan II dari gambar diatas disebut public self, yakni aspek diri yang 
diketahui orang lain. Sedangkan bagian III dan IV adalah private self, yakni aspek diri yang tidak diketahui orang lain. Bagian I dan III dari jendela ini merupakan aspek diri yang diketahui oleh diri pribadi. Sebaliknya, bagian II dan IV merupakan aspek diri yang tidak diketahui oleh diri pribadi yang bersangkutan.

\subsection{Teori Disonansi Kognitif dan Konsistensi Afektif-Kognitif}

Teori Disonansi Kognitif dikemukakan oleh Leon Festinger tahun 1957. Teori disonansi kognitif merupakan teori yang membahas ketidaknyamanan mengenai perasaan seseorang akibat pemikiran, sikap, dan perilaku yang saling bertentangan dan momotivasi seseorang untuk mengambil langkah demi mengurangi ketidaknyamanan tersebut.

Menurut Secord dan Backman (1964) dalam Azwar (2016), Teori ini berasumsi bahwa komponen afeksi senantiasa berhubungan dengan komponen kognisi dan orang berusaha membuat kognisinya konsisten dengan afeksinya. Dengan kata lain, keyakinan seseorang, pendirian seseorang, dan pengetahuan seseorang tentang suatu fakta sebagian ditentukan oleh pilihan afeksinya. Konsekuensinya bila terjadi perubahan dalam komponen afeksi akan menimbulkan perubahan pada komponen kognisi. Untuk itu dalam mengubah sikap, maka komponen afeksi diubah lebih dahulu kemudian akan mengubah komponen kognisi serta diakhiri dengan perubahan sikap.

Dari hasil kajian teori dan pola kerangka pemikiran yang telah dilakukan, selanjutnya dilakukan hipotesis dari model penelitian:

Gambar 1. Hipotesis Model Penelitian

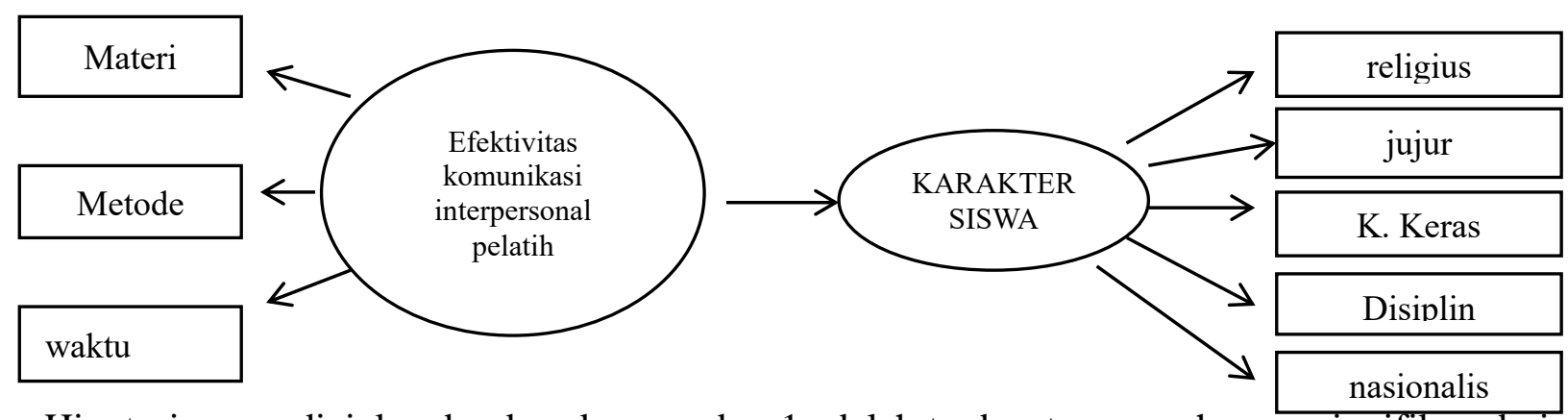

Hipotesis yang diajukan berdasarkan gambar 1 adalah terdapat pengaruh yang signifikan dari efektifitas komunikasi interpersonal pelatih terhadap karakter siswa Sekolah Sepakbola di kota Palembang.

Populasi dalam penelitian ini adalah siswa sekolah sepakbola (SSB) di Kota Palembang dengan kategori usia siswa yaitu 13 - 17 tahun. Dalam penelitian ini, peneliti memilih siswa dari 6 Sekolah Sepakbola yang ada di kota Palembang, karena:

a. Memiliki jumlah siswa yang banyak dibandingkan dengan Sekolah Sepakbola (SSB) yang lain,

b. Memiliki manajemen yang bagus, baik dari segi administrasi, sarana penunjang latihan, prestasi, dan lisensi pelatih.

\section{Metode Penelitian}

Analisis data dalam penelitian ini menggunakan analisis statistik deskriptif dan analisis inferensial. Analisis statistik deskriptif dilaksanakan untuk menyajikan data hasil riset dalam 
bentuk tabel maupuan grafik, sedangkan analisis statistik inferensial memakai Structural Equation Modelling (SEM), berfungsi untuk menguji hipotesis penelitian serta berbagai asumsi yang harus dipenuhi. Data dianalisis dengan menggunakan software statistic LISREL 8.7 Variabel efektivitas komunikasi interpersonal pelatih meliputi: materi, metode, dan waktu; sedangkan variabel karakter siswa dibatasi pada: religius, jujur, kerja keras, disiplin, dan nasionalis.

Penelitian ini diawali dengan melakukan kajian teori dari beberapa pustaka tentang variabel efektivitas komunikasi interpersonal pelatih (Variabel Eksogen) dan variabel karakter siswa (Variabel Endogen). Dari hasil kajian teori diperoleh hasil sebagai berikut :

Tabel 1. Variabel Komunikasi Interpersonal Pelatih dan siswa (Eksogen)

\begin{tabular}{cc}
\hline INDIKATOR & KODE \\
\hline Materi & X1 \\
Metode & X4 \\
Waktu & X5 \\
\hline
\end{tabular}

Sumber: Sahlan dan Prastyo (2012); Gunawan (2017)

Tabel 2. Variabel Karakter Siswa

\begin{tabular}{cc}
\hline INDIKATOR & KODE \\
\hline Religius & Y1 \\
Jujur & Y2 \\
Disiplin & Y3 \\
Kerja Keras & Y4 \\
Nasionalis & Y5 \\
\hline
\end{tabular}

Sumber: Sahlan dan Prastyo (2012); Gunawan (2017)

Pengolahan data menggunakan metode Structural Equation Modelling (SEM), maka jumlah sampel yang digunakan untuk estimasi ML (Maximum Likelihood) adalah $100-200$ atau minimal $5 \mathrm{X}$ banyak parameter yang diestimasi (Hair, dkk, 2014 dalam Wijanto, 2015).

Teknik Estimasi menggunakan ML (Maximum Likelihood), karena: 1). N relatif kecil (100200), dan 2). Asumsi Normalitas dipenuhi. Populasi siswa dari enam SSB semuanya berjumlah 635 orang, karena keterbatasan waktu penelitian maka peneliti mengambil sampel sebanyak 120 orang saja dan ini sudah sesuai dengan teknik estimasi menggunakan Maximum Likelihood.

\section{Hasil dan Pembahasan}

\subsection{Uji Validitas dan Reliabilitas}

Menurut Hair et al (2014) dalam Gunarto (2018) menyatakan, bahwa SEM adalah perpaduan dari analisis faktor, analisis regresi dan analisis jalur. Selanjutnya Joreskog dan Sorbom (1993) dalam Gunarto (2018) menambahkan, bahwa penggunaan SEM mampu menguji validitas dan reabilitas sebuah penelitian, mengkonfirmasi ketepatan model dan menguji pengaruh dari variabel terhadap variabel lainnya.

Hasil pengujian dari jawaban koresponden dalam penelitian efektivitas komunikasi interpersonal pelatih dalam membentuk karakter siswa sekolah sepakbola di kota Palembang, dilakukan dengan mengukur validitas dan reliabilitas pada indikator dari masing-masing variabel eksogen dan variabel endogen. Variabel eksogen adalah efektivitas komunikasi interpersonal pelatih, sedangkan variabel endogen adalah karakter siswa. 


\subsection{Variabel Efektivitas Komunikasi Interpersonal Pelatih}

Tampilan hasil estimasi konstruk efektivitas komunikasi interpersonal dalam bentuk path diagram yang terdiri dari standardized solution dan t-value bisa dilihat pada gambar 2 dan gambar 3, sebagai berikut :

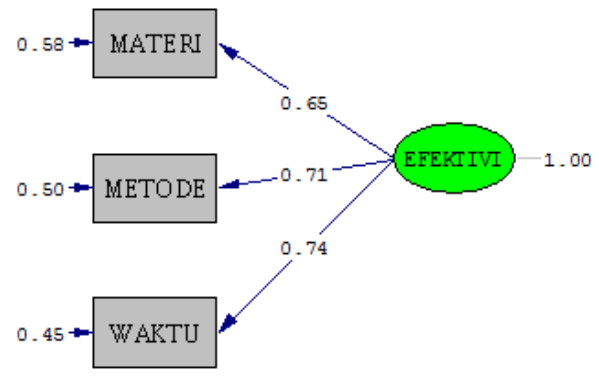

Chi-Square $=0.00, \mathrm{df}=0, \mathrm{P}-\mathrm{value}=1.00000, \mathrm{RMSEA}=0.000$

Gambar 2. Standardized Solution Konstruk Efektivitas Komunikasi Interpersonal Pelatih

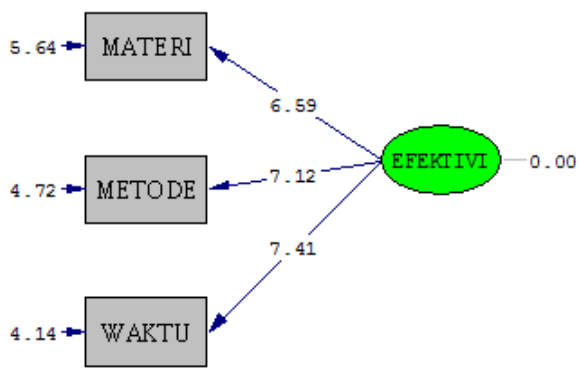

Chi-Square $=0.00, \mathrm{df}=0, \mathrm{P}-\mathrm{value}=1.00000, \mathrm{RMSEA}=0.000$

Gambar 3. T-Value Konstruk Efektivitas Komunikasi Interpersonal Pelatih

Berdasarkan hasil output estimasi Lisrel di atas, dapat dilihat bahwa semua indikator pembentuk konstruk pada efektivitas komunikasi interpersonal pelatih memiliki nilai $t$-value untuk masing-masing indikator lebih dari 1,96 dan nilai muatan faktor (loading factor) lebih dari 0,5 , sehingga dapat disimpulkan bahwa semua indikator adalah valid.

Untuk menghitung reliabilitas (CR dan AVE) digunakan nilai standard solution berikut ini:

Tabel 3. Nilai Reliabilitas Indikator Efektivitas Komunikasi

\begin{tabular}{cccc}
\hline VARIABEL & $\lambda$ & $\lambda^{2}$ & $\mathrm{e}=1-\lambda^{2}$ \\
\hline X1 (Materi) & 0,65 & 0,42 & 0,58 \\
X2 (Metode) & 0,71 & 0,50 & 0,50 \\
X3 (Waktu) & 0,74 & 0,55 & 0,45 \\
\hline Jumlah & 2,10 & 1,47 & 1,53 \\
\hline
\end{tabular}

Sumber: Hasil pengolahan data

Berdasarkan tabel di atas diperoleh nilai:

$\sum \lambda=2,10 ;$ sehingga $\left(\sum \lambda\right)^{2}=4,41$ 
$\sum \lambda^{2}=1,47 ;$ dan $\sum \mathrm{e}=1,53$

Dengan menggunakan rumus Construct Reliability (CR) dan Average Variance Extracted (AVE) diperoleh nilai

\section{Construct Reliability $(C R)$}

$\left(\sum \lambda\right)^{2}$

$=$

$\left(\sum \lambda\right)^{2}+\left(\sum \mathrm{e}\right)$

$\mathrm{CR}=4,41 /(4,41+1,53)=4,41 / 5,94=0,74$

Average Variance Extracted (AVE)

$$
=\frac{\sum \lambda^{2}}{\sum \lambda^{2}+\sum \mathrm{e}}
$$

$\operatorname{AVE}=1,47 /(1,47+1,53)=1,47 / 3=0,49=0,5$

Berdasarkan hasil perhitungan tersebut nilai $\mathrm{CR} \geq 0,7$ dan $\mathrm{AVE} \geq 0,5$, sehingga dapat disimpulkan bahwa konstruk untuk variabel Efektivitas Komunikasi Interpersonal Pelatih adalah reliabel.

\subsection{Variabel Karakter Siswa}

Tampilan hasil estimasi konstruk karakter siswa dalam bentuk path diagram yang terdiri dari standardized solution dan t-value bisa dilihat pada gambar 4 dan gambar 5, sebagai berikut

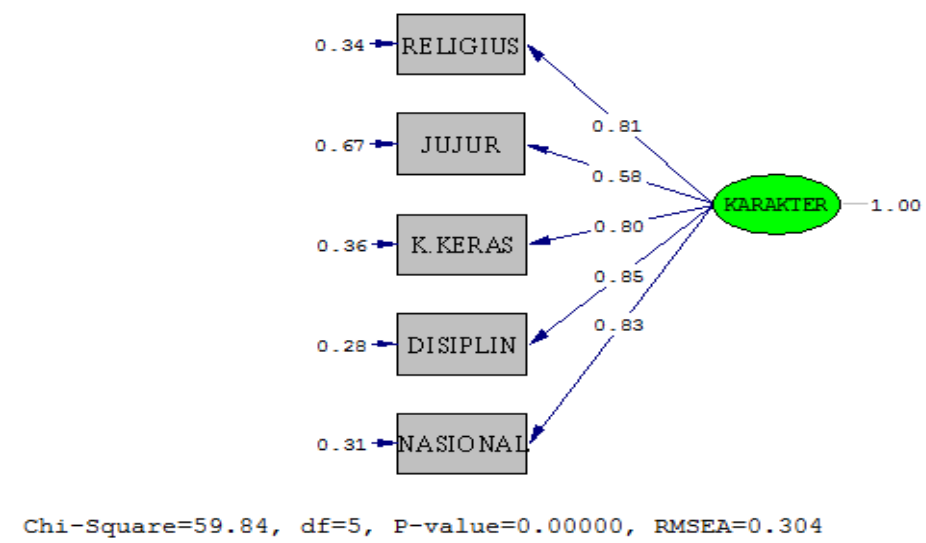

Gambar 4. Standardized Solution Karakter Siswa 


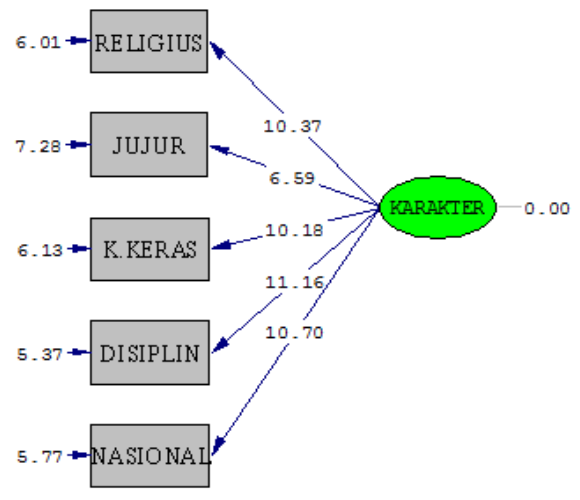

Chi-Square $=59.84, \mathrm{df}=5, \mathrm{P}-\mathrm{value}=0.00000, \mathrm{RMSEA}=0.304$

Gambar 5. T-Value Konstruk Karakter Siswa

Berdasarkan hasil output estimasi Lisrel di atas, dapat dilihat bahwa semua indikator pembentuk konstruk pada Karakter Siswa memiliki nilai t-value untuk masing-masing indikator lebih dari 1,96 dan nilai muatan faktor (loading factor) lebih dari 0,5, sehingga dapat disimpulkan bahwa semua indikator adalah valid.

Untuk menghitung reliabilitas (CR dan AVE) digunakan nilai standard solution berikut ini:

Tabel 4. Nilai Reliabilitas Karakter Siswa

\begin{tabular}{cccc}
\hline VARIABEL & $\lambda$ & $\lambda^{2}$ & $\mathrm{e}=1-\lambda^{2}$ \\
\hline Y1 & 0,81 & 0,66 & 0,34 \\
Y2 & 0,58 & 0,34 & 0,66 \\
Y3 & 0,80 & 0,64 & 0,36 \\
Y4 & 0,85 & 0,72 & 0,28 \\
Y5 & 0,83 & 0,69 & 0,31 \\
\hline Jumlah & 3,87 & 3,05 & 1,95 \\
\hline
\end{tabular}

Sumber: Hasil Pengolahan Data

Berdasarkan tabel di atas diperoleh nilai:

$\sum \lambda=3,87$; sehingga $\left(\sum \lambda\right)^{2}=14,98$

$\sum \lambda^{2}=3,05$; dan

$\sum \mathrm{e}=1,95$

Dengan menggunakan rumus CR dan AVE diperoleh nilai:

$\mathrm{CR}=14,98 /(14,98+1,95)=14,98 / 16,93=0,88=0,9$

$\mathrm{AVE}=3,05 /(3,05+1,91)=3,05 / 4,96=0,61=0,6$

Berdasarkan hasil perhitungan tersebut nilai $\mathrm{CR} \geq 0,7$ dan $\mathrm{AVE} \geq 0,5$, sehingga dapat disimpulkan bahwa konstruk untuk variabel Karakter Siswa adalah reliabel

Rekapitulasi Jawaban Siswa terhadap Efektivitas Komunikasi Interpersonal Pelatih per Indikator 
Rekapitulasi hasil jawaban siswa terhadap efektivitas komunikasi interpersonal pelatih dalam masing-masing indikator, dirangkum sebagaimana terlihat pada tabel di bawah ini.

Tabel 5. Rekapitulasi Hasil Jawaban Siswa terhadap Efektifitas Komunikasi Interpersonal Pelatih dalam Masing Masing Indikator

\begin{tabular}{ccc}
\hline Indikator & $\begin{array}{c}\text { Skor Rata-Rata Jawaban } \\
\text { Responden }\end{array}$ & Kriteria \\
\hline Materi & 3,34 & Cukup Tinggi/Cukup Baik \\
Metode & 3,46 & Tinggi/ Baik \\
Waktu & 2,98 & Cukup Tinggi/Cukup Baik \\
\hline
\end{tabular}

Sumber: Hasil Pengolahan Data

\subsection{Rekapitulasi Jawaban Siswa terhadap Karakter Siswa per Indikator}

Rekapitulasi hasil jawaban siswa terhadap karakter siswa dalam masing-masing indikator, dirangkum sebagaimana terlihat pada tabel di bawah ini.

Tabel 6. Rekapitulasi Hasil Jawaban Siswa terhadap Karakter Siswa dalam Masing Masing Indikator

\begin{tabular}{ccc}
\hline Indikator & $\begin{array}{c}\text { Skor Rata-Rata } \\
\text { Jawaban Siswa }\end{array}$ & Kriteria \\
\hline Religius & 3,18 & Cukup Tinggi/ CukupBaik \\
Jujur & 3,13 & Cukup Tinggi/ CukupBaik \\
Kerja Keras & 2,56 & Cukup Tinggi/ CukupBaik \\
Disiplin & 3,18 & Cukup Tinggi/ CukupBaik \\
Nasionalis & 3,24 & Cukup Tinggi/ CukupBaik \\
\hline
\end{tabular}

Sumber: Hasil Pengolahan Data

\subsection{Analisis SEM Pada Model Struktural}

Analisis full model dilakukan setelah terlebih dahulu menganalisa faktor konfirmatori (CFA) terhadap masing-masing variabel, selanjutnya membentuk model struktural secara fit. Setelah selesai melakukan analisis faktor konfirmatori, langkah berikutnya menganalisis full model struktural secara keseluruhan dengan hanya menggunakan indikator-indikator pembentuk konstruk yang valid.

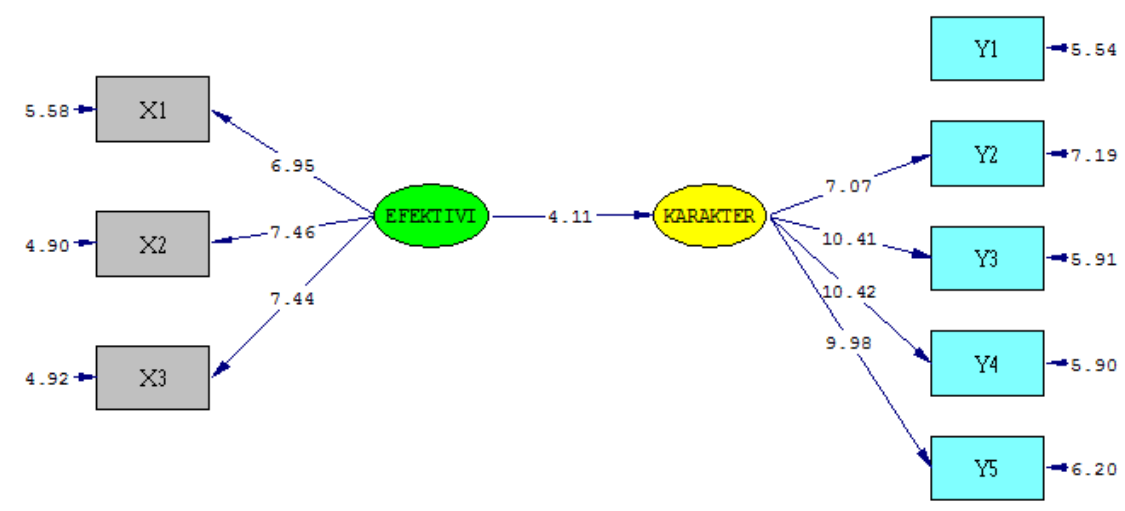

Chi-Square $=88.58, \mathrm{df}=19, \mathrm{P}-\mathrm{value}=0.00000, \mathrm{RMSEA}=0.175$

Gambar 6. Hasil Pengujian Full Model Struktural T-Value. 


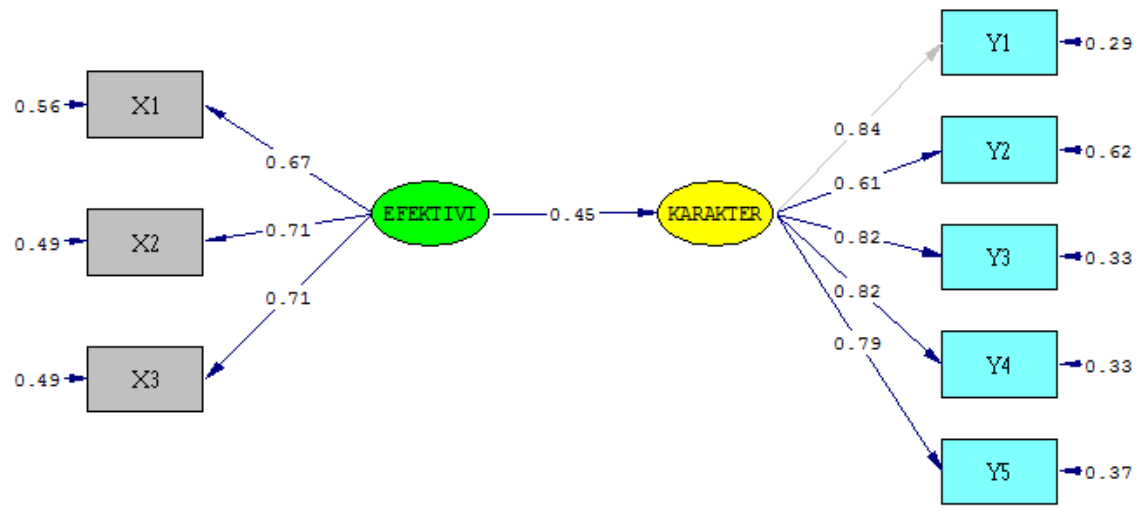

Chi-Square $=88.58, \mathrm{df}=19, \mathrm{P}-$ value $=0.00000, \mathrm{RMSEA}=0.175$

Gambar 7. Hasil Pengujian Full Model Struktural.Standardized Solution

Berdasarkan hasil output estimasi Lisrel di atas, dapat dilihat bahwa hampir semua indikator dan semua jalur yang menghubungkan variabel laten mempunyai t-value $>1,96$, hal ini menunjukkan bahwa variabel efektivitas komunikasi interpersonal pelatih berpengaruh signifikan terhadap pembentukan karakter siswa. Tetapi untuk menguji kelayakan model secara keseluruhan (full model) harus dilakukan terlebih dahulu dengan menghitung indeks Goodness of Fit Statistics seperti yang tertera pada Lampiran 1, dan secara garis besarnya terlihat pada tabel di bawah ini.

Tabel 6. Goodness of Fit Statistics Full Model

\begin{tabular}{cccc}
\hline Kriteria & Penilaian & Hasil Model & Kesimpulan \\
\hline Chi-Square & kecil & 88,58 & Tidak Fit \\
p-Value & $\geq 0,05$ & 0,00 & Tidak Fit \\
AGFI & $\geq 0,90$ & 0,70 & Tidak Fit \\
GFI & $\geq 0,90$ & 0,84 & Tidak Fit \\
RSMEA & $\leq 0,08$ & 0,17 & Tidak Fit \\
\hline
\end{tabular}

Sumber: Hasil Pengolahan Data Penelitian

Hasil perhitungan indeks Goodness of Fit Statistics seperti yang ditunjukkan pada tabel di atas, diperoleh $p$-value untuk Chi-Square adalah $\mathrm{p}=0,00000<0,05$ sehingga model tidak fit. Karena model tidak fit maka perlu dilakukan modifikasi model untuk menurunkan nilai Chi-Square dan menaikkan nilai $p$-valuenya. Hasil modifikasi model untuk mendapatkan kecocokan model dapat dilihat pada gambar di bawah ini. 


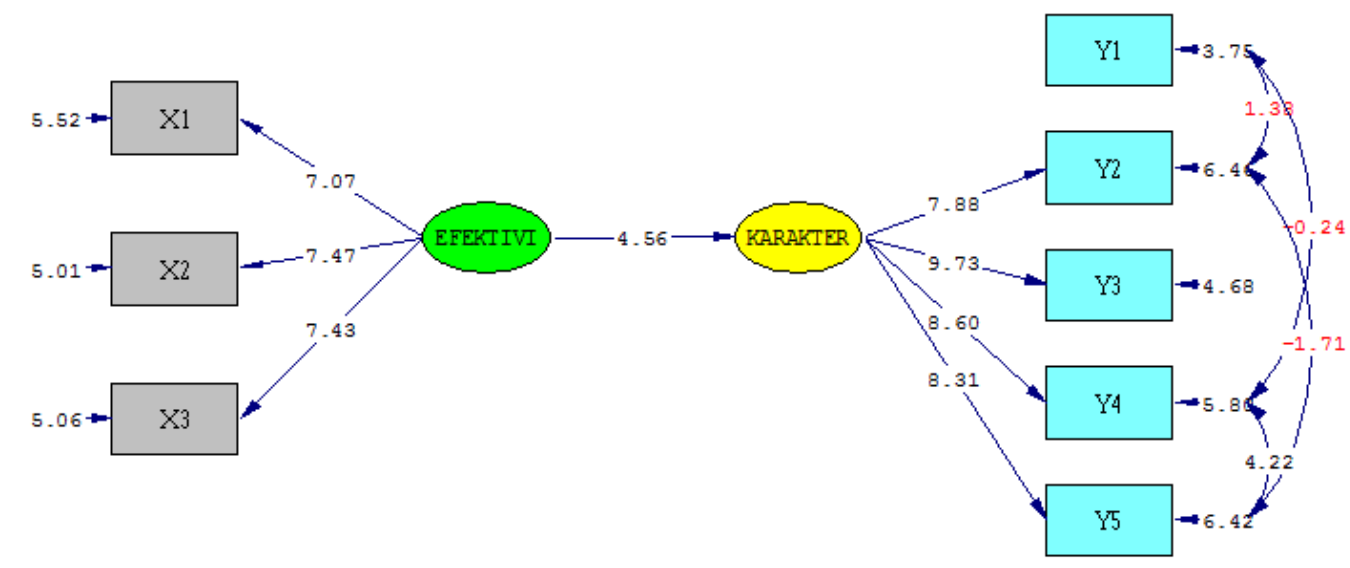

Chi-Square $=22.10, d f=15, P$-value $=0.10526$, RMSEA $=0.063$

Gambar 8. Modifikasi Full Model T-Value

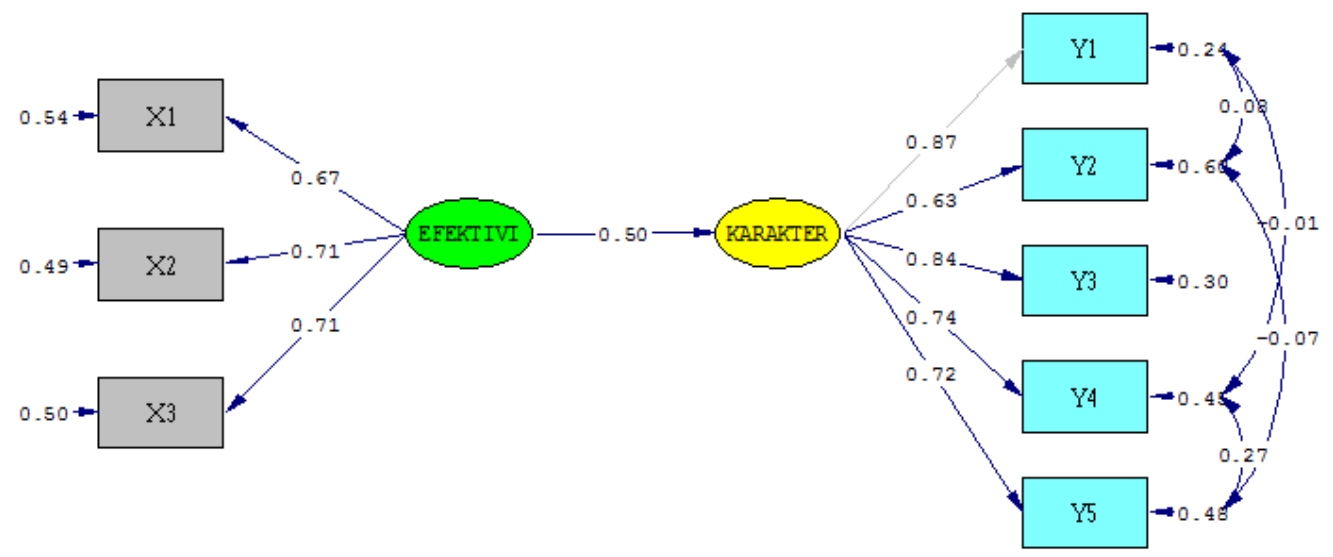

Chi-Square $=22.10, \mathrm{df}=15, \mathrm{P}-\mathrm{value}=0.10526, \mathrm{RMSEA}=0.063$

Gambar 9. Modifikasi Full Model Standardized Solution

Hasil output dari modifikasi untuk kecocokan model secara garis besarnya terlihat pada tabel di bawah ini

Tabel 7. Goodness of Fit Statistics Full Model

\begin{tabular}{cccc}
\hline Kriteria & Penilaian & Hasil Model & Kesimpulan \\
\hline Chi-Square & kecil & 22,10 & Fit \\
p-Value & $\geq 0,05$ & 0,11 & Fit \\
AGFI & $\geq 0,90$ & 0,90 & Fit \\
GFI & $\geq 0,90$ & 0,96 & Fit \\
RSMEA & $\leq 0,08$ & 0,06 & Fit
\end{tabular}

Sumber: Hasil Pengolahan Data Penelitian

Nilai chi square yang awalnya 88,58 setelah dilakukan modifikasi menjadi 22,10. Nilai p-value sebelum dimodifikasi sebesar 0,00000, setelah dimodifikasi menjadi meningkat sebesar 0,11. Berdasarkan output di atas, dapat dilihat bahwa nilai chi-square $=22,10$ dan $p$-value $=0,11$, nilai tersebut menunjukkan bahwa nilai chi-square telah menurun dan nilai $p$-value telah 
meningkat setelah dimodifikasi. Sehingga $\mathrm{p}=0,11>0,05$ maka dapat disimpulkan model sudah fit.

Langkah selanjutnya yaitu melakukan interpretasi model, dengan membuat persamaan struktural dan pengujian hipotesis dari model yang sudah fit.

\subsection{Persamaan Struktural}

Hasil output Lisrel pada Gambar 8 dan Gambar 9 di atas, dapat disusun seperti tabel berikut ini

Tabel 8. Standardized Direct Effects

\begin{tabular}{cc}
\hline & Efektivitas Komunikasi Interpersonal Pelatih \\
\hline Karakter Siswa & 0,50 \\
\hline
\end{tabular}

Berdasarkan hasil perhitungan pada Tabel 8 mengenai efektivitas komunikasi interpersonal pelatih dalam membentuk karakter siswa sekolah sepakbola di kota Palembang, menunjukkan bahwa efektivitas komunikasi interpersonal pelatih memiliki pengaruh langsung sebesar 0,50 dalam membentuk karakter siswa. Sehingga didapat persamaan Struktural seperti yang terinci dari Tabel 8 di atas adalah sebagai berikut:

$\mathrm{Y}=0,50 * \mathrm{X}$

Keterangan :

$\mathrm{Y}=$ Karakter Siswa

$\mathrm{X}=$ Efektivitas Komunikasi Interpersonal Pelatih

\subsection{Pengujian Hipotesis}

Berdasarkan gambar 8 dapat dilihat bahwa hasil perhitungan diperoleh nilai t hitung sebesar 4,56 > 1,96. Artinya dengan tingkat kesalahan sebesar 5\% dapat disimpulkan bahwa efektivitas komunikasi interpersonal pelatih berpengaruh dalam membentuk karakter siswa sekolah sepakbola di kota Palembang.

Pengujian hipotesis membuktikan bahwa efektivitas komunikasi interpersonal pelatih memiliki pengsruh yang positif dan signifikan dalam membentuk karakter siswa sekolah sepakbola di kota Palembang. Arah positif yang ditunjukkan berdasarkan analisis adalah semakin tinggi komunikasi interpersonal antara pelatih dan siswa maka akan semakin tinggi pula keberhasilan pelatih dalam membentuk karakter siswa di sekolah sepakbola kota Palembang.

Berdasarkan hasil analisis persamaan struktural hubungan variabel eksogen dan variabel endogen yaitu $\mathrm{Y}=0,50 * \mathrm{X}$, menjelaskan bahwa sebesar 50 prosen pelatih memiliki pengaruh langsung dalam membentuk karakter siswa.

Proses penyampaian pesan dari seorang pelatih kepada siswanya dapat dilakukan secara langsung maupun tidak langsung. Secara langsung misalnya dengan jalan bertatap muka menggunakan bahasa atau simbol-simbol, menggunakan bahasa isyarat, sedangkan yang tidak langsung misalnya dengan bentuk ketauladanan yang dicontohkan oleh pelatih kepada siswanya. Tujuan dari berkomunikasi adalah untuk mengubah sikap, pendapat, dan perilaku siswa agar siswa mau menjalankan perintahnya sesuai dengan peraturan yang berlaku di 
sekolah sepakbola. Perubahan yang terjadi pada siswa ini dikelompokkan sebagai perubahan kognitif, afektif, dan konatif atau behavioral.

Sekolah sepakbola didirikan dengan tujuan untuk mendidik siswa agar terampil dalam bermain bola kaki. Disamping itu juga siswa dituntut untuk bersikap dan berperilaku yang baik, sehingga terbentuk keseimbangan jasmani dan rohani yang baik. Dari hasil penelitian, peneliti mengelompokkan keefektifan pelatih dalam berkomunikasi dengan siswanya menjadi tiga bagian, yaitu pada materi, metode, serta waktu yang diterapkan di sekolah sepakbola. Sedangkan pada variabel karakter siswa yang diamati adalah sikap religius, kejujuran, kerja keras, disiplin, dan nasionalis.

Hasil observasi penelitian dengan beberapa pelatih di sekolah sepakbola Palembang, diketahui bahwa masih banyak siswa yang cenderung kurang percaya diri (pendiam, pemalu, dan minder), kurang disiplin, kurangnya kesadaran akan tanggung jawab, kurang memperhatikan pelajaran, sering mengganggu kawannya atau sering datang terlambat, sehingga permasalahan ini harus segera diselesaikan oleh pelatih agar nantinya dapat membuat sikap siswa menjadi siswa yang berkarakter (Wawancara dengan pelatih Persegrata, pelatih Putra Sukma, dan pelatih Perisai tanggal 05 Januari 2020). Untuk itu pelatih dalam mendidik siswa harus mampu memahami sikap dan perilaku siswanya. Hal itu sesuai dengan yang dianjurkan oleh Azwar (2016) bahwa pemahaman diri mengenai sikap sangat penting dalam mempelajari masalah perubahan dan pengubahan sikap, tidak saja dalam mencoba mengerti sebab-sebab berubahnya sikap seseorang terhadap sesuatu objek tetapi juga dalam memahami mengapa orang berperilaku tidak sesuai dengan sikapnya.

Sepakbola adalah permainan tim, dimana setiap siswa memiliki gaya, sikap, dan perilaku yang berbeda. Siswa ada yang memiliki sifat pendiam, pemalu, dan minder, sebaliknya ada siswa yang senang mengganggu kawannya, suka berkelahi, kurang disiplin, dan kurang bertanggung jawab. Sikap dan perilaku seperti yang didapat dari hasil observasi, dapat dijelaskan dengan model teori Johari Window

Pola-pola dari jendela Johari dapat digambarkan seperti gambar berikut :

(ST)

(STT)

\begin{tabular}{|c|c|c|}
\hline (OT) & I (ST-OT) & II (STT-OT) \\
\hline (OTT) & III (ST-OTT) & IV (STT-OTT) \\
\hline
\end{tabular}

Sumber: Hutagalung, 2007; Harapan dan Ahmad, 2014

Keterangan:

ST = Saya Tahu

STT $=$ Saya Tidak Tahu

OT $=$ Orang lain Tahu

OTT $=$ Orang lain Tidak Tahu

(known to self)

(not known to self)

(known to others)

(not known to others). 
Pelatih yang mampu memahami model teori jendela window, tentunya akan mengangkat moral siswanya yang memiliki rasa ketidakpercayaan diri, minder, malu, bersifat arogan menjadi siswa yang siap untuk menghadapi tantangan dan tidak boleh takut menghadapi kegagalan. Siswa yang kurang percaya diri karena mempunyai daerah publik (I) yang kecil sedangkan daerah III yaitu daerah tersembunyi lebih besar, atau si siswa tadi memiliki daerah buta yang lebih besar karena kemampuan atau kelebihan pada dirinya tidak tahu, padahal menurut orang lain siswa tadi memiliki kemampuan. Untuk itulah peran pelatih begitu penting untuk membuka daerah terbuka (ruang I), sebab semakin meluas daerah terbuka (Ruang I) siswa akan mempunyai konsep diri yang positif. Siswa akhirnya mengetahui kelemahan dan kekuatan pada dirinya yang akhirnya menjadi pribadi yang matang dan percaya diri.

Kegiatan pembelajaran di sekolah sepakbola (SSB) kota Palembang terdiri dari tiga tahapan, yang terdiri dari kegiatan pendahuluan, kegiatan inti, dan kegiatan penutup. Dari hasil pengamatan, peneliti memperoleh gambaran bahwa perilaku pelatih sepanjang proses pembelajaran merupakan model pelaksanaan nilai-nilai karakter bagi siswa. Pelatih adalah guru bagi siswanya, pelatih harus punya peran sebagai fasilitator, motivator, partisipan, dan pemberi umpan balik. Petuah Ki Hajar Dewantara, bahwa pelatih juga harus mampu mengembangkan nilai-nilai karakter pada siswanya, yakni dengan berlaku sebagai ing ngarsa sung tuladha (di depan pelatih berperan sebagai teladan atau memberi contoh), ing madya mangun karsa (di tengah-tengah siswa, pelatih diharapkan membangun prakarsa dan bekerja sama dengan siswa), tut wuri handayani (di belakang pelatih mampu memberi daya semangat dan dorongan bagi siswa).

Pada tahap pendahuluan, ada beberapa cara yang dilakukan oleh pelatih untuk mengenalkan nilai-nilai karakter pada siswanya, diantaranya adalah pelatih datang tapat pada waktunya, dengan harapan akan menanamkan nilai-nilai disiplin pada siswanya. Pelatih mengucapkan salam dengan ramah, diteruskan dengan mengucapkan kata-kata pemberi semangat kepada siswanya. Hal ini akan berpengaruh kepada perilaku siswa untuk membiasakan bersikap santun, peduli, dan rasa bangga sebagai bangsa Indonesia. Berdoa bersama sebelum memulai pembelajaran agar tertanam nilai religius. Pelatih menegur siswa yang terlambat dengan sopan, agar tertanam karakter disiplin, santun, dan peduli. Penanaman nilai-nilai karakter pada tahap pendahuluan ini akan mengubah dan membentuk perilaku siswa menjadi siswa yang berkarakter. Siswa didorong untuk mengurangi atau menghilangkan sikap disonansi kognitif, yakni dengan menghilangkan ketidaknyamanan atau ketegangan psikologis disebabkan pertentangan sikap dan kenyataan yang ada pada diri siswa. Sehingga sifat malas, sifat rendah diri, sering terlambat berlatih, sifat suka berkelahi dari diri siswa lambat laun akan berubah dan menjadi siswa yang berkarakter religius, disiplin, santun, kerja keras, dan bangga sebagai bangsa Indonesia.

Pada kegiatan inti, pelatih menggunakan beragam pendekatan untuk melatih siswanya, yakni selalu melakukan pendekatan yang terukur terhadap siswa atau anak didik agar mereka merasa dekat dan tidak ada jarak, sehingga mereka akan selalu terbuka kepada pelatihnya dan tidak mudah tersinggung karena sudah mengetahui sifat dan karakter pelatihnya. Serta sebagai seorang pelatih kita harus selalu memberikan motivasi-motivasi yang dapat menimbulkan kepercayaan diri seorang pemain. Dengan berbagai cara 
pendekatan yang dilakukan oleh pelatih akan menanamkan nilai-nilai kerja keras, disiplin, nasionalis pada siswanya.

Memfasilitasi peserta didik melakukan latihan secara individu, misalnya bagaimana memberi contoh cara menendang bola ke arah tiang jauh, memberikan contoh bagaimana mengontrol bola dengan dada, memberi contoh gerakan tanpa bola, menyundul bola, dan sebagainya. Hal ini akan menanamkan nilai-nilai mandiri, kerja sama, dan kerja keras pada diri siswa.

Memfasilitasi peserta didik melakukan game dan berkompetisi secara sehat, hal ini akan menanamkan nilai-nilai kejujuran, disiplin, kerja keras, saling menghargai. Kegiatan penutup. Dalam kegiatan penutup, pelatih bersama-sama dengan siswa melakukan penilaian dan/atau refleksi terhadap kegiatan yang sudah dilaksanakan, maka akan tertanam nilai kejujuran, mengetahui kelebihan dan kekurangan masing-masing individu.

\section{Kesimpulan}

Analisis SEM adalah teknik analisis yang dilakukan untuk menyelesaikan permasalahan pada model-model struktural. Model Struktural adalah model dimana satu variabel bisa menjadi variabel independent, namun di sisi lain menjadi variabel dependent. Analisis SEM dapat digunakan: untuk melakukan uji validitas pada masing-masing indikator setiap variabel melalui analisis CFA (Confirmatory Factor Analysis). Analisis SEM bisa melihat pengaruh langsung dan tidak langsung pada model struktural antar variabel, dan bisa melakukan prediksi dari model yang terbentuk, jika model yang diperoleh memiliki GoF (Goodness of Fit) yang baik

Berdasarkan analisis stratistik model persamaan struktural (Structural Equation Modelling) diperoleh nilai $t$-value sebesar 4,56 > 1,96 dan Standardized Solution sebesar 0,50. Artinya disimpulkan bahwa efektivitas komunikasi interpersonal pelatih berpengaruh positif dan signifikan dalam membentuk karakter siswa sekolah sepakbola di kota Palembang. Efektivitas komunikasi interpersonal pelatih memiliki pengaruh langsung sebesar 50 prosen dalam membentuk karakter siswa. Semakin tinggi efektivitas komunikasi interpersonal antara pelatih dan siswa akan semakin meningkatkan dalam pembentukan karakter siswa, sehingga nantinya terbentuk siswa yang berkarakter religius, jujur, kerja keras, disiplin, dan nasionalis berdasar Pancasila.

Berdasarkan keterbatasan penelitian ini disarankan untuk melakukan penelitian dengan menggunakan variabel second order, sehingga diperoleh penelitian lanjutan yang lebih mendetail sehingga akan diperoleh informasi yang lebih mendalam mengenai hubungan komunikasi interpersonal pelatih dan karakter siswa sekolah sepakbola.

\section{Referensi}

Azwar, S. (2016). Sikap Manusia Teori dan Pengukurannya. Yogyakarta: Pustaka Pelajar.

De Vito, J.A. (2018). Komunikasi Antar Manusia. Edisi Kelima, Tangerang Selatan: Kharisma Publishing Group

Gunarto, M. (2018). Analisis Statistika Dengan Model Persamaan Struktural (SEM): Teoritis dan Praktis. Bandung: Alfabeta.

Gunawan, H. (2017). Pendidikan Karakter: Konsep dan Implementasi. Bandung: Alfabeta. 
Harapan, E., \& Syarwani, A. (2004). Komunikasi Antar Pribadi. Jakarta: PT. Raja Grafindo Persada.

Hutagalung, I. (2007). Pengembangan Kepribadian Tinjauan Praktis Menuju Pribadi Positif. Jakarta: PT. Macanan Jaya Cemerlang.

West, R., \& Turner, L.H. (2017). Pengantar Teori Komunikasi Analisis dan Aplikasi. Jakarta: Salemba Humanika

Wijanto, S.H. (2015). Metode Penelitian Menggunakan Structural Equation Modeling dengan Lisrel 9. Jakarta: Lembaga Penerbit Fakultas Ekonomi Universitas Indonesia

\section{Copyrights}

Copyright for this article is retained by the author(s), with first publication rights granted to the journal.

This is an open-access article distributed under the terms and conditions of the Creative Commons Attribution license (http://creativecommons.org/licenses/by/4.0/) 